\title{
Enzyme-triggered Radical Reactions: Another Approach For Tin-free Radical Chemistry
}

\author{
Ibrahima Cissokho ${ }^{a}$, Anne-Marie Farnet ${ }^{b}$, Elisée Ferréb ${ }^{b}$ Michèle P. Bertrand ${ }^{a}$, Gérard Gilc \\ and Stéphane Gastaldi ${ }^{\star a}$
}

\begin{abstract}
The system laccase/mediator/dioxygen is able to trigger radical reactions with radical precursors which are not natural substrates of this enzyme. The radical generation has been accomplished by single electron transfer oxidation of a 1,3-dicarbonyl precursor. The process is exemplified with a radical cascade.
\end{abstract}

Keywords: 1,3-Dicarbonyl compounds · Laccase $\cdot$ Oxidoreductase $\cdot$ Radical mediator $\cdot$ Radical reaction

Over the last few years, our research group has explored the possibility to broaden the synthetic potential of radical reactions by combining them with an enzymatic transformation. This led us to report the first switchable dynamic kinetic resolution (DKR) process allowing the synthesis of either $(R)$ - or $(S)$-amides from racemic amines depending on the nature of the enzyme, lipase or protease. ${ }^{11]}$ This fruitful adventure in the world of hydrolases led us to think about the possibility to use an enzyme to initiate radical reactions. The latter can be initiated through a redox reaction. ${ }^{[2]}$ This second approach might be achieved with the assistance of an oxidoreductase. Indeed, numerous redox reaction, such as oxidation of alcohol, aldehyde or ketone, hydroxylation of aromatic or nonactivated carbon atoms, can be catalyzed by isolated enzymes. ${ }^{[3,4]}$ Oxidase, a subclass of the oxidoreductases, is constituted of any enzyme that catalyzes an oxidation-reduction reaction involving molecular oxygen as the final electron acceptor.[5] In these reactions, oxygen is reduced to water or to hydrogen peroxide. In order to avoid the formation of hydrogen peroxide in the reaction medium that might induce side reactions, laccases have been selected for this preliminary study since, with these copper-containing oxidases, ${ }^{[5 b, 6]}$ the only side-product formed during the redox process is water (Scheme 1).

Laccases have a low redox potential (0.5-0.8 V/NHE) ${ }^{[6,7]}$ which explains why their natural substrates are mainly electron-rich phenols. ${ }^{[6 a]}$ To extend the scope of applications to non-phenolic substrates, a redox mediator can be used (Fig. 1). The role of mediators in laccase oxidations is

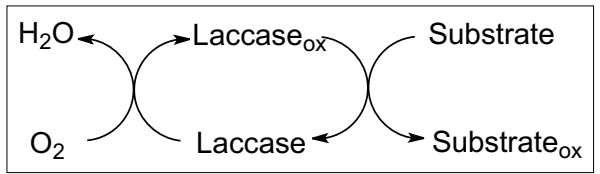

Scheme 1. depicted in Scheme 2. ${ }^{[8]}$ They act as 'electron shuttles'; after being oxidized by the enzyme, the oxidized form of the mediator oxidizes any substrate that could not enter in the enzymatic pocket.

Moreover, the wide structural variety of oxidized mediators enables the reaction to evolve through oxidation mechanisms that cannot be catalyzed by the enzyme alone, and thus to broaden the range of potential substrates (Scheme 2). Thus PT and ABTS radical cations lead to single electron transfer (SET) reactions (Fig. 1). ${ }^{9]}$ $N$-Hydroxy mediator-derived radicals (e.g. HBT, HPI) enable the abstraction of a hydrogen atom from benzylic positions. ${ }^{[9 a, 10]}$

In the present paper, we describe our recent results on the use of the laccase-mediator system to initiate a radical reaction on radical precursors which are not laccase classical substrates.

SET oxidative processes that enable the generation of radicals are interesting

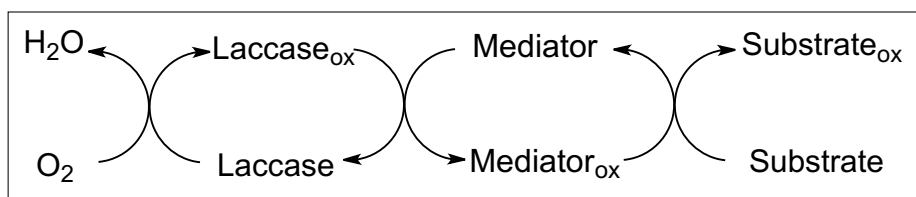

Scheme 2

Fig. 1. Examples of mediators.

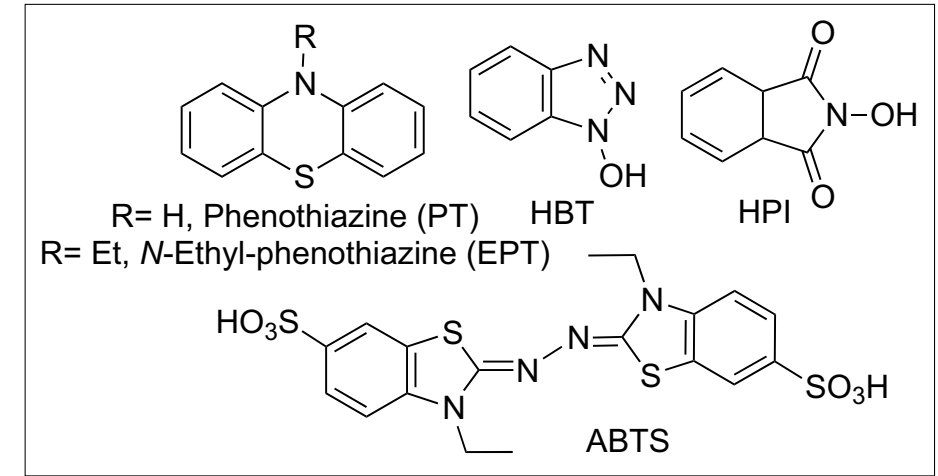

$\mathrm{R}=\mathrm{H}$, Phenothiazine (PT) HBT

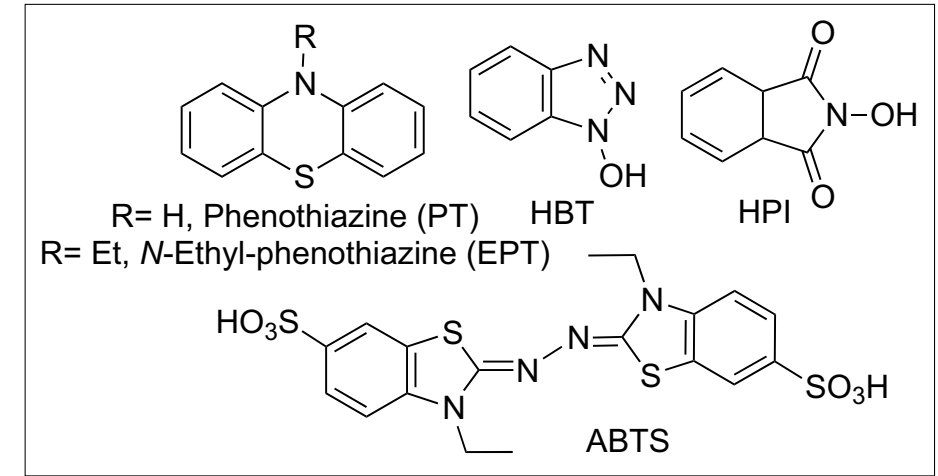
HPI O 


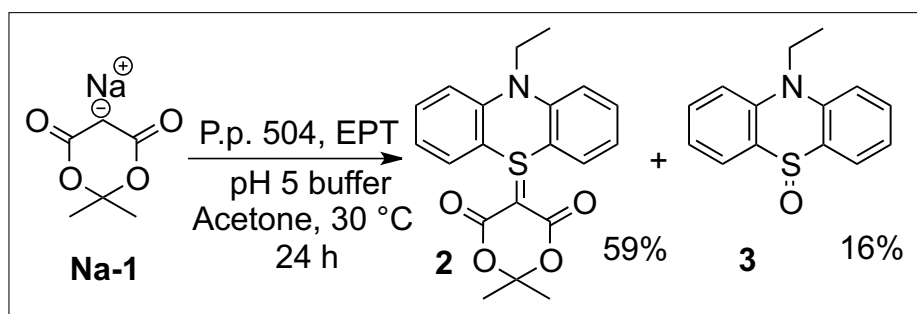

Scheme 3.

alternatives to tin-based methodologies. ${ }^{[11]}$ Carbon-centered radicals have been generated from neutral carbonyl derivatives, carbanions, enamines or enolates by employing, among other oxidants, $\mathrm{Mn}(\mathrm{OAc})_{,},{ }^{[12]}$ ceric ammonium nitrate (CAN), ${ }^{[13]} \operatorname{copper(II)}{ }^{[14]}$ or iron(III) ${ }^{[14 a, b, 15]}$ complexes. The main drawback of these methodologies is that the oxidant is often used in excess and it is difficult to get rid of metal traces. This problem may be easily overcome by the enzymatic approach. Indeed, laccases enable the use of a catalytic amount of enzymes since the co-oxidant of the reaction is dioxygen. Moreover, the copper atoms in charge of the oxidation are strongly liganded to the enzyme and from this point of view the medium can be considered as metal-free at the end of the process.

The goal of this preliminary study was to trigger, with a laccase, a radical reaction from a substrate which is not a classical enzyme substrate. To reach this goal, it was necessary to select a mediator capable to act as an 'electron shuttle', between the enzyme and the substrate, during the reaction. Thus ABTS and Meldrum's acid were selected as mediator and radical precursor respectively. The strong acidity of this 1,3-dicarbonyl compound enables the use of the corresponding sodium salt, as substrate in the buffer aqueous medium required to maintain the enzyme active. The commercially available laccase Polyporus pinsitus 504 (P.p. 504)[16] from Novo Nordisk was selected so that the methodology could easily be reproduced or extended to other substrates.

When Meldrum's acid (1) or its sodium salt (Na-1) was reacted with the radical cation of ABTS $\left(\mathrm{ABTS}^{\bullet+}\right)^{[17]}$ (1 equiv.), generated in the presence of P.p. 504 in a pH 5 succinate buffer solution, no evolution, like dimerization, was detected and the dark blue color of $\mathrm{ABTS}^{\bullet+}$ remained unchanged. Another mediator, $\mathrm{N}$-ethylphenothiazine (EPT), ${ }^{[18,19]}$ was used under the same conditions. The light orange color of $\mathrm{EPT}^{\circ+}$ became violet instantaneously after addition of Na-1 before turning again light orange at the end of the reaction (24 $\mathrm{h})$. The analysis of the mixture showed that ylide $2^{[20]}$ together with sulfoxide $\mathbf{3}$ were formed in 59 and $16 \%$ yield respectively (Scheme 3). The same result was observed starting from 1, showing that at $\mathrm{pH} 5$ the equilibrium between both forms enabled the reaction to proceed.

The formation of $\mathbf{2}$ might be explained on the grounds of the mechanism proposed in Scheme 4. After a first electron transfer (ET) step from EPT to the enzyme, EPT $^{*+}$ oxidized Na-1/1 through a second ET generating radical A. The latter was then trapped by the persistent $\mathrm{EPT}^{\cdot+}(\mathbf{B})^{[21]}$ which evolved to $\mathbf{2}$ after deprotonation. The concomitant formation of $\mathbf{3}$ resulted from the reaction of $\mathrm{EPT}^{\circ+}$ with water. The structure of $\mathbf{3}$ was confirmed by comparison with an authentic sample produced by a direct oxidation of EPT with $m$-CPBA, ${ }^{[22]}$ in this case the corresponding sulfone was also produced. The latter was not detected during the enzyme-catalyzed reaction.

This transformation was applied to other acidic 1,3-dicarbonyl compounds. Acetylacetone and dimedone led to $\mathbf{4}$ and 5 in 58 and $78 \%$ yield (Fig. 2) whereas a less acidic substrate like ethyl cyanoacetate did not undergo any transformation. It must be underlined that the formation of sulfoxide 3 could not be avoided.

This first approach showed that a commercially available laccase could be used as catalyst to generate a carbon-centered radical. However, the nature of the couple laccase/mediator had to be optimized in order to preclude any interference of the mediator with the fate of the radical species. In spite of the rather disappointing preliminary results obtained with ABTS, we decided to reinvestigate its reactivity. The absence of evolution, when the reaction was performed with $\mathbf{1}$, did not necessarily mean that the oxidation of the dicarbonyl compound did not occur. The interesting point was that if the oxidation proceeded the resulting radical did not react with the mediator.

With this purpose in mind, Meldrum's acid was functionalized with an efficient internal radical acceptor, ${ }^{[23]}$ i.e. a styrene

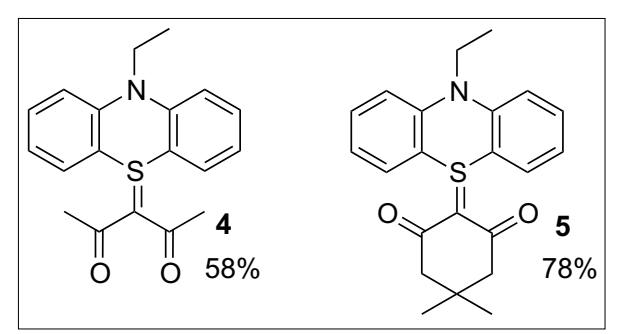

Fig. 2.

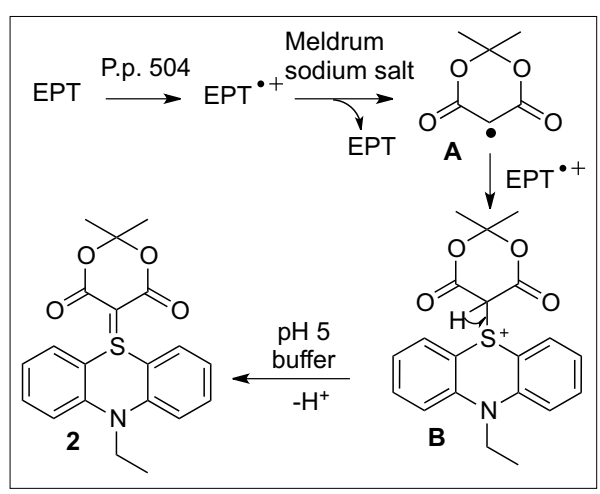

Scheme 4.

moiety (6). No transformation occurred in the presence of EPT contrary to the reactivity previously observed with unsubstituted 1,3-dicarbonyl compounds.

On the other hand, when a solution of 6 in toluene was added to the dark blue buffered solution of ABTS ${ }^{\bullet+}$, a slow discoloration of the solution was observed. ABTS was added by portion until the blue color became persistent ( 0.6 equiv.). After consumption of the substrate (TLC monitoring, $3 \mathrm{~h}$ ), the reaction was stopped and analyzed. Cyclopropane 7 was characterized as a mixture of two diasteromers (1:1). Its formation might be explained by the mechanism proposed in Scheme 5. The $\alpha$-dicarbonyl radical $\mathbf{C}$, resulting from the oxidation of $\mathbf{6}$, added reversibly to the double bond. Equilibrium was then displaced by the oxidation of radical $\mathbf{D}$ with $\mathrm{ABTS}^{\bullet+}$ leading to the benzylic cation $\mathbf{E}$ which was trapped by a molecule of water to form 7 in $38 \%$ yield. This radical-polar crossover cascade showed that ABTS was able to act first as 'electron shuttle' between the laccase and the radical precursor and second as final oxidant. However the modest yield and the quantity of mediator used in the process, 0.6 equiv., confirmed previous observations that ABTS might give rise to byproducts and therefore it was not the best mediator for a selective reaction. ${ }^{[24]}$

In summary, this preliminary study showed that the couple laccase/mediator, with dioxygen as co-oxidant, is a viable alternative to initiate a radical reaction involving a redox process. This new method of radical generation enables the formation, at $30^{\circ} \mathrm{C}$, of $\mathrm{C}-\mathrm{C}$ bond and subsequent functionalization. This system might be improved by the design of new mediators which will not interfere with the radical cascade. These results will be reported in due course.

\section{Experimental Section}

Solvents are commercially available, they were used as purchased, without further purification. Purifications were per- 


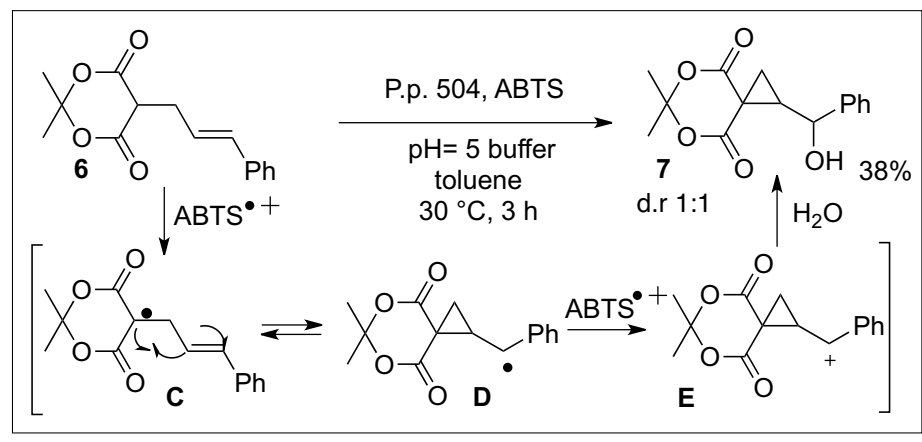

Scheme 5.

formed on Macherey Nagel silica gel 60 A (70-230 mesh). Analytical thin layer chromatography was performed on pre-coated silica gel plates. Visualization was accomplished by UV (254 $\mathrm{nm}$ ) and with phosphomolybdic acid in ethanol. ${ }^{1} \mathrm{H}$ NMR, ${ }^{13} \mathrm{C}$ NMR spectra were recorded at $400 \mathrm{MHz}$ and $100 \mathrm{MHz}$, respectively. Chemical shifts $(\delta)$ are reported in ppm. Signals due to residual undeuteriated solvent $\left({ }^{1} \mathrm{H}\right.$ NMR) or to the solvent $\left({ }^{13} \mathrm{C}\right.$ NMR) served as the internal standards: $\mathrm{CDCl}_{3}(7.26 \mathrm{ppm}$ and $77.0 \mathrm{ppm})$. Multiplicity is indicated by one or more of the following symbols: $s$ (singlet), d (doublet), t (triplet), q (quartet), $\mathrm{m}$ (multiplet), br (broad). The lists of coupling constants $(J)$ correspond to the order of multiplicity assignment and are reported in Hertz (Hz). APT was used for ${ }^{13} \mathrm{C}$ spectra assignment.

\section{Enzyme Assay}

The crude laccase from Polyporus pinsitus (P.p. 504) from Novo Nordisk (170 $\mathrm{mg}$ ) was diluted in $2 \mathrm{~mL}$ of $\mathrm{pH} 5$ succinate buffer $(0.2 \mathrm{M})$ and corresponds to P.p. 504 enzymatic extract in the following. Enzyme activity $(1.93 \mu \mathrm{m} / \mathrm{min} / \mathrm{mg})$ was measured by monitoring the oxidation of syringaldazine ${ }^{[25]}$ to the corresponding quinone $\left(\varepsilon^{\mathrm{M}}=65000 \mathrm{M}^{-1} \mathrm{~cm}^{-1}\right)$ at $525 \mathrm{~nm}$ in succinate buffer $0.1 \mathrm{M}, \mathrm{pH} 4.0$ on a spectrophotometer Uvikon XL. One unit (U) of laccase activity is defined as the amount of enzyme that oxidizes $1 \mu \mathrm{mol}$ of the substrate per minute per $\mathrm{g}$.

\section{General Procedure for Ylide Synthesis}

To 10-ethylphenothiazine ${ }^{[18]}(91.2 \mathrm{mg}$, $0.4 \mathrm{mmol})$ in a mixture of acetone $(3.2 \mathrm{~mL})$ and $\mathrm{pH} 5$ succinate buffer $(32 \mathrm{~mL})$ at $30^{\circ} \mathrm{C}$ was added P.p. 504 enzymatic extract (100 $\mu 1)$. The solution was stirred $30 \mathrm{~min}$ before addition of 1.3-dicarbonyl compound (0.4 $\mathrm{mmol}$ ). After $24 \mathrm{~h}$ stirring, the reaction medium was extracted with $\mathrm{CH}_{2} \mathrm{Cl}_{2}(3 \mathrm{x})$, the combined organic phases were dried over $\mathrm{MgSO}_{4}$. After concentration, the crude product was purified by flash chromatography on silica gel (5/95 to $100 / 0 \mathrm{AcOEt} /$ pentane) leading to the title compound.

\section{5-(10-Ethyl-10H-phenothiazin-5-} ylidene)-2,2-dimethyl-1,3-dioxane4,6-dione (2)

${ }^{1} \mathrm{H} \mathrm{NMR}\left(\mathrm{CDCl}_{3}\right): 7.60(\mathrm{dd}, J=6.4$ and 1.6, $2 \mathrm{H}$ ), 7.50 (ddd, $J=8.7,7.2$ and 1.6, $2 \mathrm{H}), 7.22(\mathrm{~d}, J=8.3,2 \mathrm{H}), 7.11($ broad $\mathrm{t}, J=$ $8.0,2 \mathrm{H}), 4.26(\mathrm{q}, J=7.2,2 \mathrm{H}), 1.53(\mathrm{~s}, 6 \mathrm{H})$, $1.56(\mathrm{t}, J=7.2,3 \mathrm{H}) .{ }^{13} \mathrm{C} \mathrm{NMR}\left(\mathrm{CDCl}_{3}\right)$ : $163.0 \quad\left(\mathrm{C}=\mathrm{O}_{\text {ester }}\right), \quad 142.9 \quad\left(\mathrm{C}_{\text {arom }}\right), \quad 133.2$ $\left(\mathrm{CH}_{\text {arom }}\right), 130.7\left(\mathrm{CH}_{\text {arom }}\right), 122.4\left(\mathrm{CH}_{\text {arom }}\right)$, $115.4\left(\mathrm{CH}_{\text {arom }}\right), \quad 106.8 \quad\left(\mathrm{C}_{\text {arom }}\right), \quad 103.2$ $(\mathrm{O}-\mathrm{C}-\mathrm{O}), 60.4(\mathrm{C}=\mathrm{S}), 40.0\left(\mathrm{CH}_{2}-\mathrm{N}\right), 26.1$ $\left(2 \mathrm{xCH}_{3}\right), 12.9\left(\mathrm{CH}_{3}\right)$. HRMS $\left([\mathrm{M}+\mathrm{Na}]^{+}\right.$, ESI): $m / z$ calcd for $\mathrm{C}_{20} \mathrm{H}_{19} \mathrm{NO}_{4} \mathrm{SNa}$ : 392.0927. Found: 392.0921.

\section{3-(10-Ethyl-10H-phenothiazin-5- ylidene)pentane-2,4-dione (4)}

${ }^{1} \mathrm{H}$ NMR $\left(\mathrm{CDCl}_{3}\right): 7.43(\mathrm{td}, J=7.2$ and $1.4,2 \mathrm{H}), 7.38$ (dd $J=7.8$ and 1.2, 2H), 7.13 (m superimposed, 2H), $7.04(\mathrm{t}$, $J=7.3,2 \mathrm{H}), 4.22(\mathrm{q}, J=7.1,2 \mathrm{H}), 2.47$ $(\mathrm{s}, 6 \mathrm{H}), 1.52(\mathrm{t}, J=7.1,3 \mathrm{H}) .{ }^{13} \mathrm{C}$ NMR $\left(\mathrm{CDCl}_{3}\right): 189.7(\mathrm{C}=\mathrm{O}), 142.0\left(\mathrm{C}_{\text {arom }}\right), 132.0$ $\left(\mathrm{CH}_{\text {arom }}\right), 128.5\left(\mathrm{CH}_{\text {arom }}\right), 121.8\left(\mathrm{CH}_{\text {arom }}\right)$, $114.8\left(\mathrm{CH}_{\text {arom }}\right), 110.3\left(\mathrm{C}_{\text {arom }}\right), 97.8(\mathrm{C}=\mathrm{S})$, $43.2\left(\mathrm{CH}_{2}-\mathrm{N}\right), 29.7\left(2 \mathrm{xCH}_{3}\right), 12.6\left(\mathrm{CH}_{3}\right)$. HRMS ([M+H $]^{+}$, ESI): $\mathrm{m} / z$ calcd for $\mathrm{C}_{19} \mathrm{H}_{20} \mathrm{NO}_{2} \mathrm{~S}: 326.1209$. Found: 326.1208.

\section{2-(10-Ethyl-10H-phenothiazin-5- ylidene)-5,5-dimethylcyclohexane- 1,3-dione (5)}

${ }^{1} \mathrm{H}$ NMR $\left(\mathrm{CDCl}_{3}\right): 7.44$ (m superimposed, $4 \mathrm{H}), 7.17(\mathrm{~d}, \mathrm{~J}=8.9,2 \mathrm{H}), 7.04(\mathrm{t}, \mathrm{J}=$ $7.3,2 \mathrm{H}), 4.29$ (q, J = 7.1, 2H), $2.26(\mathrm{~s}, 4 \mathrm{H})$, $1.55(\mathrm{t}, \mathrm{J}=7.1,3 \mathrm{H}), 0,96(\mathrm{~s}, 6 \mathrm{H}) .{ }^{13} \mathrm{C} \mathrm{NMR}$ $\left(\mathrm{CDCl}_{3}\right): 191.1(\mathrm{C}=\mathrm{O}), 142.5\left(\mathrm{C}_{\text {arom }}\right), 132.4$ $\left(\mathrm{CH}_{\text {arom }}\right), 130.0\left(\mathrm{CH}_{\text {arom }}\right), 121.8\left(\mathrm{CH}_{\text {arom }}\right)$, $114.7\left(\mathrm{CH}_{\text {arom }}\right), 107.9\left(\mathrm{C}_{\text {arom }}\right), 99.5(\mathrm{C}=\mathrm{S})$, $43.5\left(\mathrm{CH}_{2}-\mathrm{N}\right), 31.0\left(\mathrm{CH}_{2}\right), 29.0(\mathrm{C}), 28.2$ $\left(2 \mathrm{xCH}_{3}\right), 12.6\left(\mathrm{CH}_{3}\right)$. HRMS $\left([\mathrm{M}+\mathrm{H}]^{+}\right.$, ESI): $m / z$ calcd for $\mathrm{C}_{22} \mathrm{H}_{24} \mathrm{NO}_{2} \mathrm{~S}: 366.1522$. Found: 366.1521 .

\section{Cyclization of 6}

To ABTS (22.1 mg, 0,04 mmol) in $\mathrm{pH}$ 5 succinate buffer $(32 \mathrm{~mL})$ at $30{ }^{\circ} \mathrm{C}$ were added P.p. 504 enzymatic extract (400 $\mu \mathrm{L})$, the color of the solution becomes dark blue. Then (E)-2,2-dimethyl-5-(3'phenylallyl)-1,3-dioxane-4-6-dione ${ }^{[23]}$ (209 $\mathrm{mg}, 0.8 \mathrm{mmol})$ in toluene $(20 \mathrm{~mL})$ was added. The solution was stirred and each time the color turned yellow ABTS was added by portion ( $7 \times 22 \mathrm{mg})$ until the color remained blue. Once the reaction finished (TLC monitoring, $3 \mathrm{~h}$ ), the diphasic solution was extracted with AcOEt (3x) and dried over $\mathrm{MgSO}_{4}$. After concentration, the crude product was purified by flash chromatography on silica gel (10/90 to $20 / 80 \mathrm{AcOEt} /$ pentane) leading to 7 (84 $\mathrm{mg}, 0.3 \mathrm{mmol}, 38 \%$ ) as a mixture of diasteromers, further purification enables the isolation of pure samples of each isomers for characterization. Isomer 7a: ${ }^{1} \mathrm{H}$ NMR $\left(\mathrm{CDCl}_{3}\right): 7.32-7.42(\mathrm{~m}, 5 \mathrm{H}), 4.84(\mathrm{~d}, J=$ $9.6,1 \mathrm{H}), 2.60(\mathrm{q}, J=9.2,1 \mathrm{H}), 2.13(\mathrm{~m}$, 2H), 1.98 (s, 3H), 1.78 (s, 3H). ${ }^{13} \mathrm{C}$ NMR $\left(\mathrm{CDCl}_{3}\right): 168.1\left(\mathrm{C}_{\text {ester }}\right), 166.5\left(\mathrm{C}_{\text {ester }}\right), 142.1$ $\left(\mathrm{C}_{\text {arom }}\right), 129.0\left(\mathrm{CH}_{\text {arom }}\right), 128.6\left(\mathrm{CH}_{\text {arom }}\right)$, $126.0\left(\mathrm{CH}_{\text {arom }}\right), \quad 105.9 \quad(\mathrm{O}-\mathrm{C}-\mathrm{O}), \quad 71.7$ (-CH-O), 45.5 (-CH-C), 29.4 (-C-), 27.8 $\left(\mathrm{CH}_{3}\right), 27.7\left(\mathrm{CH}_{3}\right), 25.5\left(\mathrm{CH}_{2}\right)$. Isomer 7b: ${ }^{1} \mathrm{H} \mathrm{NMR}\left(\mathrm{CDCl}_{3}\right): 7.35(\mathrm{~m}, 5 \mathrm{H}), 4.85(\mathrm{~d}, J$ $=8.4,1 \mathrm{H}), 2.72(\mathrm{q}, J=8.4,2 \mathrm{H}), 2.13(\mathrm{~m}$, 2H), 1.98 (s, 3H), 1.78 (s, 3H) ${ }^{13} \mathrm{C}$ NMR $\left(\mathrm{CDCl}_{3}\right): 167.8\left(-\mathrm{C}=\mathrm{O}_{\text {ester }}\right), 166.5\left(\mathrm{C}=\mathrm{O}_{\text {ester }}\right)$, $141.8\left(-\mathrm{C}={ }_{\text {rom }}\right), 129.1^{\text {ester }}\left(=\mathrm{CH}_{\text {arom }}\right), 128.9$ $\left(=\mathrm{CH}_{\text {arom }}\right), 126.7\left(\mathrm{CH}_{\text {arom }}\right), 105.3(\mathrm{O}-\mathrm{C}-\mathrm{O})$, 71.6 (-CH-O), 44.7 (-CH-C), 28.5 (-C-), $28.0\left(-\mathrm{CH}_{2}-\right), 27.5\left(\mathrm{CH}_{3}\right), 26.5\left(\mathrm{CH}_{3}\right)$. HRMS $\left(\left[\mathrm{M}+\mathrm{NH}_{4}\right]^{+}, \mathrm{ESI}\right): \mathrm{m} / z$ calcd for $\mathrm{C}_{15} \mathrm{H}_{20} \mathrm{NO}_{5}$ : 294.1336. Found: 294.1341.

\section{Acknowledgements}

Gift of laccase from Polyporus pinsitus (P.p. 504) from Novo Nordisk is gratefully acknowledged.

Received: February 21, 2012

[1] a) S. Gastaldi, S. Escoubet, N. Vanthuyne, G. Gil, M. P. Bertrand, Org. Lett. 2007, 9, 837; b) L. El Blidi, M. Nechab, N. Vanthuyne, S. Gastaldi, M. P. Bertrand, G. Gil, J. Org. Chem. 2009, 74, 2901; c) L. El Blidi, N. Vanthuyne, D. Siri, S. Gastaldi, M. P. Bertrand, G. Gil, Org. Biomol. Chem. 2010, 8, 4165; d) F. Poulhès, $\mathrm{N}$. Vanthuyne, M. P. Bertrand, S. Gastaldi, G. Gil, J. Org. Chem. 2011, 76, 7281.

[2] Y. Kita, M. Matsugi, in 'Radical in Organic Synthesis', Eds. P. Renaud, M. Sibi, WileyVCH: Weinheim, 2001, Vol. 1, pp 1-10.

[3] For a recent review on oxidoreductases, see: D Monti, G. Ottolina, G. Carrea, S. Riva, Chem. Rev. 2011, 111, 4111 and references cited therein.

[4] For a review on enzyme-mediated oxidation, see: F. Hollmann, I. W. C. E Arends, K. Buehler, A. Schallmey, B. Buehler, Green Chem. 2011, $13,226$.

[5] For reviews on oxidases see: a) E. I. Solomon, A. J. Augustine, J. Yoon, Dalton Trans. 2008 , 3921; b) E. I. Solomon, U. M. Sundaram, T. E. Machonkin, Chem. Rev. 1996, 96, 2563; c) S. Fetzner, R. A. Steiner, Appl. Microbiol. Biotechnol. 2010, 86, 791

[6] a) P. Baldrian, FEMS Microbiol. Rev. 2006, 30 215; b) H. Claus, Micron 2004, 35, 93 ; c) A. M. Mayer, R. C. Staples, Phytochemistry 2002, 60 , 551. For a review on applications of laccases, see: S. Rodriguez Couto, J. L. Toca Herrera, Biotech. Adv. 2006, 24, 500.

[7] F. Xu, W. Shin, S. H. Brown, J. A. Wahleithner, U. M. Sundaram, E. I. Solomon, Biochim. Biophys. Acta 1996, 1292, 303. 
[8] a) R. Bourbonnais, D. Leech, M. G. Paice, Biochim. Biophys. Acta 1998, 1379, 381; b) M. Husain, Q. Husain, Crit. Rev. Env. Sci. Tec. 2008, 38,1 .

[9] a) P. Baiocco, A. M. Barreca, M. Fabbrini, C. Galli, P. Gentili, Org. Biomol. Chem. 2003, 1, 191; b) M. Fabbrini, C. Galli, P. Gentili, J. Mol. Catal. B 2002, 16, 231.

[10] a) R. Bernini, F. Crisante, P. Gentili, F. Morana, M. Pierini, M. Piras, J. Org. Chem. 2011, 76, 820; b) G. Cantarella, C. Galli, P. Gentili, New J. Chem. 2004, 28, 366; c) P. Astolfi, P. Brandi, C. Galli, P. Gentili, M. F. Gerini, L. Grecia, O. Lanzalunga, New J. Chem. 2005, 29, 1308.

[11] For a review on SET reactions, see: P. I. Dalko, Tetrahedron 1995, 51, 7579.

[12] For reviews, see a) B. B. Snider, Chem. Rev. 1996, 96, 339; b) G. G. Melikyan, Org. React. 1997, 49, 427.

[13] a) For a review, see: V. Nair, J. Mathew, J. Prabhakaran, Chem. Soc. Rev. 1997, 26, 127; b) A.-C. Durand, E. Dumez, J. Rodriguez, J.-P. Dulcère, Chem. Commun. 1999, 2437.

[14] For selected examples, see: a) M. Schmittel, A. Burghart, W. Malisch, J. Reising, R. Söliner, J. Org. Chem. 1998, 63, 396; b) Y. Ito, T. Konolke, T. Harada, T. Saegusa, J. Am. Chem. Soc. 1977, 99, 1487; c) P. S. Baran, B. D. Hafensteiner, N.
B. Ambhaikar, C. A. Guerrero, J. D. Gallagher, J. Am. Chem. Soc. 2006, 128, 8678; d) U. Jahn, D. Rudakov, Org. Lett. 2006, 8, 4481; e) G. Sorin, R. Martnez Mallorquin, Y. Contie, A. Baralle, M. Malacria, J-P. Goddard, L. Fensterbank, Angew. Chem. Int. Ed. 2005, 44, 609.

[15] For selected examples, see: a) T. Cohen, K. McNamara, M. A. Kuzemko, K. Ramig, J. J. Landi, Jr., Tetrahedron 1993, 49, 7931; b) M. P. Sibi, M. Hasegawa, J. Am. Chem. Soc. 2007, 129, 4124; c) U. Jahn, P. Hartmann, E. Kaasalainen, Org. Lett. 2004, 6, 257; d) U. Jahn, M. Müller, S. Aussieker, J. Am. Chem. Soc. 2000, 122, 5212; e) J-P, Goddard, C. Gomez, F. Brebion, S. Beauvière, L. Fensterbank, M. Malacria, Chem. Commun. 2007, 2929.

[16] The $\mathrm{E}^{\circ}$ redox potential of P.p. 504 has been measured (0.79 V/NHE): D. S. Yaver, F. Xu, E. J. Golightly, K. M. Brown, S. H. Brown, M. W. Rey, P. Schneider, T. Halkier, K. Mondorf, H. Dalboge, Appl. And Environ. Microbiol. 1996, 62,834 .

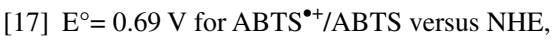
see ref. [7b].

[18] S. Ebdrup, M. Schou Jensen, P. Veds $\emptyset$, J. Chem Soc., Perkin Trans. 1 1998, 351.
[19] EPT potential redox was not found in the literature, but $\mathrm{E}^{\circ}$ for similar structures are reported: $\mathrm{E}^{\circ}=1.03 \mathrm{~V}$ for $\mathrm{N}$-methylphenothiazine $(\mathrm{MPT}) / \mathrm{MPT}^{\bullet+}$ versus NHE, D. Sun, S. V. Rosokha, J. K. Kochi, J. Am. Chem. Soc. 2004, 126, 1388; $\mathrm{E}^{\circ}=0.925 \mathrm{~V}$ for promethazine $(\mathrm{PMZ}) / \mathrm{PMZ}^{\bullet+}$ versus NHE, E. Madej, P. Wardman, Radiat. Phys. Chem. 2006, 75, 990.

[20] Close structures have recently been reported: X. Huang, R. Goddard, N. Maulide, Angew. Chem. Int. Ed. 2010, 49, 8979 .

[21] For examples of coupling of an alkyl radical with a sulfur-centered radical cation, see: J. A Murphy, in 'Radical in Organic Synthesis', Eds. P. Renaud, M. Sibi, Wiley-VCH: Weinheim, 2001, Vol. 1, pp 298-315 and references cited therein.

[22] M. Tosa, C. Paizs, C. Majdic, L. Poppe, P. Kolonits, I. A. Silberg, L. Novak, F.-D. Irimie, Heterocycl. Commun. 2001, 7, 277.

[23] G. Bélanger, F. Lévesque, J. Pâquet, G. Barbe, J. Org. Chem. 2005, 70, 291.

[24] A. M. Farnet, A. C. Chevremont, G. Gil, S. Gastaldi, E. Ferré, Chemosphere 2011, 82, 284.

[25] J. M. Harkin, J. R. Obst, Experientia 1973, 29, 381. 